\title{
GARACTERIZACIÓN GENERAL DE LA LEXICOGRAFÍA HEBREA ANDALUSÍ
}

\author{
José Martínez Delgado \\ Universidad de Granada
}

\section{Resumen}

El creciente interés por la técnica lexicográfica me sugiere presentar, a manera de esbozo, los orígenes y características de la fructífera lexicografia hebrea andalusí. En las siguientes páginas pretendo ensayar por vez primera una periodización de esta técnica y presentar sus orígenes, evolución y sus principales características, ilustrado, en la medida de lo posible, con textos originales. Se trata en definitiva de ofrecer una aproximación a esta prolífica técnica medieval tal y como se desarrolló en la Península Ibérica durante cinco siglos.

Palabras clave: Lexicografía científica, Hebreo, Judeoárabe, Al-Andalus, Edad Media.

\section{AbStract}

Due to the increasing interest in lexicographical techniques, I have decided to present a panoramic view of the origins and characteristics of the fruitful Andalusian Hebrew lexicography. In the following pages, I will try to provide, for the first time, a chronological division and to introduce the origins, evolution and main characteristics of this technique, illustrating with original texts, as far as possible. My aim is to offer an introduction to this prolific medieval technique as it was developed in the Iberian Peninsula over five centuries.

Key Words: Scientific lexicography, Hebrew, Judaeo-Arabic, Andalus, Middle Ages.

\section{INTRODUCGIÓN ${ }^{1}$}

En la cultura andalusí, cada una de las disciplinas que componían las ciencias del lenguaje ('ulüm al-lugia en el caso de los musulmanes y diqdūq halašon en el de los judíos) coexistían en simbiosis y unas se nutrían de las otras movidas por el fuerte imperativo teológico de la época ${ }^{2}$. En el caso de la lexicografía hebrea andalusí, desarrollada al regazo de la cultura árabe, esta simbiosis disciplinar se encargó de conferirle una calidad científica que disfrutó de la aceptación general de todos los estudiosos y usuarios (iğmāa $)$, im-

\footnotetext{
${ }^{1}$ Este trabajo se ha desarrollado en el marco del proyecto de investigación HUM2006-02495/FILO (Lengua y Literatura del Judaísmo Clásico: Rabínico y Medieval). Para la descripción de hechos y fenómenos lexicográficos se han seguido las directrices y planteamientos propuestos por Manuel Seco, Manuel Alvar Ezquerra y José Álvaro Porto Dapena entre otros, además de los trabajos de Salvador Peña y Juan Pablo Arias dedicados a la lexicografía árabe.

${ }^{2}$ Sobre los orígenes de esta lexicografía teológica véase Morag 1985, pp. 61-68; Zubiri 1994, p. 33; Haywood 1965, pp.1-10; Dotan 1971; 'Umar 1982, pp. 55-73.
} 
plantándose como modelo único durante siglos. La teología condicionó la labor de los lexicógrafos, que ya desde el siglo x d.C. comenzaron a madurar su técnica gracias al fuerte móvil academicista, implantado en los círculos intelectuales, que les llevaba a intentar recoger en sus obras la totalidad del lenguaje ${ }^{3}$.

La lexicografía hebrea medieval es muy rica, no sólo por la cantidad de obras sino también por la calidad e importancia de éstas, pues a partir de ellas se configuraban y dependían numerosas disciplinas de la época. Esta técnica nace en los ambientes judíos a partir del estudio de la Biblia y es impensable separar o aislar en la Edad Media los diccionarios hebreos de las Escrituras. De ahí, por tanto, que los lexicógrafos hebreos medievales concentren todos sus esfuerzos en la aclaración de las voces recogidas en la versión original de su Texto revelado.

Los diccionarios han sido siempre empleados como herramientas didácticas básicas y, de hecho, estas obras siempre han pretendido en la medida de sus posibilidades cumplir o satisfacer esta función tan poco reconocida. Los diccionarios hebreos medievales no son, como ocurre hoy en día, obras de consulta, sino de lectura corrida. Por lo general el usuario esperaba, tras su lectura, entender o interpretar la Biblia. Así, la función del diccionario consistía en acrecentar los conocimientos del usuario para elaborar exégesis, expresarse en hebreo y, principalmente, entender la Biblia en su forma original desde la propia realidad del creyente. Desde un punto de vista más práctico el diccionario se encargaba de resolver dudas concernientes al sentido, etimologías léxicas, carácter poético de determinados pasajes, etc. Por lo tanto, la meta de esta lexicografía bíblica era, ante todo, aumentar los conocimientos sobre la lengua de la Biblia para entender su mensaje. La existencia de los diccionarios bilingües, hebreo árabe, nos permite sobreentender, además, una ayuda a la traducción ${ }^{4}$. Conforme iban apareciendo obras, los usuarios se encontraban con nuevas limitaciones y eran precisamente estas carencias las que configuraban la forma, tendencia y contenido de los nuevos léxicos. A su vez, estas innovaciones establecían las diferencias entre unos y otros diccionarios configurando un intenso y brillante proceso de evolución.

Desde comienzos del siglo x se redactan importantísimas obras en forma lexicográfica fuera de la península Ibérica, destacando tres focos: Babilonia ${ }^{5}$,

\footnotetext{
${ }^{3}$ Blachère 1973, pp. 125-129. De hecho, el Mahberet 'Diccionario' de Měnahem ben Saruq (Córdoba siglo $\mathrm{x}$ ), primer léxico hebreo-hebreo de la Historia, ya es un fiel seguidor de las corrientes de su época y pretende llegar a abarcar plenamente la lengua hebrea y hacerla inteligible en toda su extensión (Sáenz-Badillos 1986, p. 1*).

${ }^{4}$ Para esta conclusión véase Maman 2004, p. 135.

${ }^{5}$ Destaca la figura de Sa'adyah Gaón (882-942), el más antiguo de los gramáticos según la tradición andalusí y autor, entre otras obras, de Ha-'Egron, Kïtāb ușül al-šìr al-'ibrāni 'El Tesoro, Libro de raíces/ fundamentos de la poesía hebrea' (Allony 1969); y su Kitäb al-sab 'in lafza 'Libro de las setenta palabras' - esto es, las que aparecen una sola vez en la Biblia- (Allony 1958).
} 
Palestina $^{6}$ y norte de África ${ }^{7}$. Por lo general, están redactadas en árabe, es decir, se trata de repertorios léxicos bilingües, pues esa era la lengua en la que se enseñaba y se expresaban. Estas obras estudian uno u otro aspecto de la lengua durante la primera mitad de esa centuria o, a partir de la segunda mitad del siglo $\mathrm{x}$, pretenden abarcar la totalidad de la lengua. Es precisamente en estos tratados pioneros donde se ensayan y fijan las herramientas lexicográficas básicas que más tarde llegarán a su máximo desarrollo en al-Andalus, tales como la ordenación alfabética de lemas, la ley de la sinonimia o sustitución, un frecuente uso de la semitística comparada y la búsqueda de un método gramatical que armonizase contexto y morfología.

\section{Períodos de la leXicografí́a hebrea ANDALusíi ${ }^{8}$}

A manera de ensayo general pueden reconocerse dos grandes períodos básicos en la historia de la lexicografia hebrea andalusí. Un primer período de producción o clásico (siglos X-XII) en el que se ensaya la fijación de un método válido y se redactan obras monográficas muy importantes, principalmente en árabe; y un segundo que podríamos denominar de difusión (siglos XII-XV) en el que se elaboran compendios, generalmente en hebreo y especialmente fuera de la península Ibérica, siempre sometidos a las tendencias fijadas en el período anterior o clásico. Sin embargo, un análisis más detallado nos permite establecer las siguientes subdivisiones:

\subsection{Período pregramatical (mediados del siglo $\mathrm{x}$ )}

Los autores desconocen las leyes que rigen la morfología hebrea. Su método pregramatical está arraigado en la tradición más antigua. Durante este

\footnotetext{
${ }^{6}$ El representante mejor conocido es, sin duda, David Ben Abraham al-Fāsī y su importantísimo The Hebrew-Arabic Dictionary of the Bible Knowen as Kitāb Jāmi' al-Alfāz (Agron) of David ben Abraham al-Fasi (Skoss 1936).

${ }^{7}$ El representante principal de este foco es Yěhuda Ibn Qurayš, principal y precoz exponente de la semitística comparada. Su obra se conoce como Al-Risāla 'La Epístola' de Yěhuda Ibn Qurayš (Becker 1984). Junto a Ibn Qurayš, también en el norte de África, tenemos noticias de Dunaš ben Tamīm al-Qayrawānī, apodado al-Sallaġi 'el descalabrador'. Su obra gramatical se da por perdida y conocemos su existencia gracias a citas de autores posteriores, que la consideran anterior e inferior a la desarrollada por Ibn Qurayš.

${ }^{8}$ Este ensayo de periodización es ilustrativo y no pretende, en ningún caso, ser definitivo. Por lo general, he basado mi criterio en la disposición y contenido de las obras. De hecho, quizá lo apropiado hubiese sido dedicar un apartado específico a los dos grandes diccionarios de la primera mitad del siglo XI y sólo después haber introducido los opúsculos monográficos que se redactaron, en algunos casos, antes o a la par que estos grandes léxicos. La misma duda puede quedarle al especialista cuando incluyo en un mismo período a autores tan alejados en el tiempo como Ibn Chiqatella e Ibn Barūn, sin embargo, ha sido el contenido monográfico de sus obras lo que me ha llevado a entenderlos como componentes de un mismo período. Lo cierto es que no tenemos datos ni referencias sobre la mayoría de los autores y en demasiadas ocasiones las obras no nos han llegado completas, si es que han se han conservado, y aún quedan muchas en manuscrito pendientes de análisis. Un catálogo muy actualizado sobre filología en al-Andalus puede encontrarse en Sáenz-Badillos 2000.
} 
periodo, los lexicógrafos hebreos no son capaces de fijar determinadas raíces ni de identificar grupos morfológicos. La disposición lexicográfica de sus obras y la ordenación de lemas está inspirada en los grandes léxicos islámicos, destacando entre todos el pionero Kitāb al-'ayn 'Libro de la <letra> 'ayn' de alde Basora (siglo VIII) y sus versiones. La obra más representativa y colosal de este período es el Mahberet 'Diccionario' de Mĕnahem ben Saruq (c. 910 - d. 960) que desató una tremenda polémica en su época9 ${ }^{9}$ Las obras de este período están redactadas en hebreo ${ }^{10}$. En el análisis lexicográfico no se diferencia aún entre hebreo y arameo dado que ambos son parte integrante de la Biblia.

Mĕnahem ben Saruq parece haber sido autodidacta. Era un hombre peculiar, fiel a su tradición, que trató de componer un diccionario de las lenguas de la Biblia en hebreo intentando siempre explicarla desde su propia tradición, sin influencias externas, aunque próximas, como el hebreo rabínico, o contemporáneas, como el árabe y la semitística comparada que comenzaba a emerger en el norte de África. No hay siquiera una sola alusión en toda la obra a la existencia de la lengua árabe. Tampoco se aceptan más permutas que las de las letras 'alef, he', waw y yod ${ }^{11}$. Se trataba, en definitiva, de escribir un libro sobre la Biblia hebrea en lengua hebrea, en un contexto judío y que todos pudiesen entender, estudiar y consultar. Mĕnaḥem ben Saruq consideró las raíces atendiendo a esa primitiva concepción atomista, gráfica y semántica que se desprende de la Masora (v. más adelante 3.1) y que repercute con especial énfasis en los verbos débiles y geminados hebreos, pues en ese momento se en-

${ }^{9}$ El Mahberet se vio envuelto en la polémica desde el momento de su aparición. Dunaš ben Labraț (c. 920-985), que se había ganado el favor de su mecenas Hasday Ibn Šaprūṭ (c. 910-970) adaptando la métrica árabe para escandir versos hebreos, vio en el Mahberet una oportunidad única para redactar una obra de tinte polémico, que le permitiese ascender aún más y ratificarse como el principal erudito de la lengua hebrea. Según él, el Mahberet contenía pasajes de marcada naturaleza herética que podían descarriar la fe de los usuarios, pues si alguien yerra en la interpretación pero no la pone por escrito, con él queda su yerro y sobre él revierte su equivocación; pero si alguien escribe un libro con errores y equivocaciones, muchas almas resultan muertas por su culpa (Sáenz-Badillos 1980a, p. 17). La crítica de Dunaš ben Labraț no viene a aportar nada nuevo, pues se centra en minucias lingüísticas y no supone ningún avance en materia lingǘstica. De hecho, como denuncian los discípulos de Měnahem ben Saruq, son muchos los puntos que ben Labraț no ha entendido. Esta polémica supuso la caída en desgracia de ben Saruq, quien perdió el favor de su mecenas, su casa fue demolida, fue azotado en público y encarcelado. En este punto, el autor del Mahberet desaparece de la historia y no sabemos nada más sobre su paradero o suerte. Tres de sus discípulos, Yěhuda ben Dāwūd (c.940-c.1000), Yișhaq Ibn Caprón (siglo x) y Yiṣhaq Ibn Chiqatella (siglo $\mathrm{x}$ ), se encargaron de salir en su defensa, redactando unas Responsa contra Dunaš ben Labraț en la que se defendían los valores locales frente a los ataques de alguien venido de fuera. En esta obra, Yěhuda ben Dāwūd (en árabe Abū Zakariya' Yahyyà Ibn Dāwūd), apodado Hayyūğğ, llevaba a cabo, por primera vez, la adaptación gramatical, de manera implícita también, del paradigma fáala para la lengua hebrea. En un primer momento, muy experimental, se trata de ordenar esquemas nominales para lanzar ataques contra la métrica adaptada por Dunaš ben Labraț. Sobre esta polémica véase además Sáenz Badillos - Targarona 1988, pp. 23-89.

${ }^{10}$ Este legado literario está compuesto por las siguientes obras: Maḥberet Menahem. (Sáenz-Badillos 1986); Těšubot de Dunaš ben Labrat (Sáenz-Badillos 1980a); Těšubot de los Discípulos de Mĕnahem ben Saruq (Benavente Robles 1986); Těšubot de Měhudah Ibn Šešet (Varela 1981); y Sefer Těšubot Dunaš ha-Levi ben Labrat 'al Rabi'Sa'adyah Gaon (Schröter 1866).

${ }^{11}$ Sobre la permuta y metátesis de consonantes como herramienta hermenético-lexicográfica véase Sáenz Badillos - Targarona 1988, pp. 139-140. 
tendían compuestos por una combinación mínima de consonantes necesaria para reconocer una voz ${ }^{12}$. Esta concepción atomista del fundamento semántico (yěsod) como raíz-lema provocará que el Mahberet reúna brillantemente citas bíblicas en un mismo campo de contexto que, aunque morfológicamente sean diferentes para generaciones futuras, siempre serán, semánticamente, iguales. Estas divisiones permanecerán presentes en todas las obras de lingüística hebrea y los filólogos idearán todo tipo de teorías para excusarlas, pero nunca las descalificarán o negarán. Según este método gramatical primitivo, el estudio de cada caso particular y de su entorno semántico será la única herramienta que ayude al que interprete las Escrituras. Muchos de sus criterios, como sus definiciones, el rechazo de los nombres propios como parte del discurso, su fijación en las permutas de las letras que luego serán denominadas débiles o la distribución de los campos semánticos y sus ambivalencias, quedarán fosilizados en todos los diccionarios bíblicos redactados en al-Andalus. Era algo general en todos los ambientes judíos cultos del siglo $\mathrm{x}$ la ausencia de un método gramatical válido. A Mĕnahem ben Saruq le correspondió el mérito de adaptar y adoptar un criterio lexicográfico consecuente y acorde con las tendencias intelectuales de su época, sin sacrificar la propia tradición judía más antigua.

\subsection{Período clásico o gramatical (segunda mitad del siglo $x$ - mediados del siglo XI)}

Durante esta fase los autores prefieren redactar sus obras en árabe (con caracteres hebreos) pues de esa lengua están tomando la terminología y la metodología ${ }^{13}$. Es decir, describían y enseñaban la lengua hebrea desde las mismas categorías con las que habían estudiado el árabe clásico en las escuelas o madrazas. En este período se descubren las leyes que rigen a la morfología hebrea y se catalogan medio millar de raíces débiles y geminadas, con sus acepciones y comportamientos, desconocidas hasta ese momento. Los autores que destacan son Abū Zakariya' Yahyyà Ibn Dāwūd (Fez c. 940 - Córdoba c. 1000), conocido

\footnotetext{
${ }^{12}$ Se trata de tradiciones ancestrales comunes reflejadas en la Masora, y así lo demuestra el criterio seguido para la fijación de lemas en el diccionario del caraíta al-Fāsī (siglo x) y la similitud con el método seguido por los autores de piyyut (poesía litúrgica) en sus derivaciones bilíteras. Sobre este punto véase Dotan 2005, pp. 61 y ss.

${ }^{13}$ El hebreo queda reservado al ámbito de la poesía, y emerge en la zona una variante nueva del árabe medio, el «judeo-árabe» andalusí. Surge como idioma culto, similar al de oriente, mezclado con tecnicismos metalingüísticos hebreos, fijados por la tradición judía, y con otras particularidades del hebreo que el árabe no puede expresar pero sí describir perfectamente. Es una lengua académica, pero muy viva y peculiar: no todo lo hebreo está en hebreo y en ocasiones los nombres de las letras del alefato son sustituidos por su equivalente árabe. La aplicación de los criterios gramaticales árabes a la lengua hebrea provoca la aparición de este nuevo idioma culto, variante judía de la lengua soberana, bien conocida por todos los usuarios cultos de la época. Este factor garantizaba el éxito y la difusión, tanto de la redacción como del criterio aplicado, pues era una adaptación de las corrientes intelectuales del momento. Es un efecto más en la gestación de esa multiculturalidad andalusí que enriquecía a la poesía hebrea en ese mismo momento y lugar. Sobre el judeo-árabe en general véase Gallego 2006. Para el judeo-árabe empleado por los autores andalusíes en particular, véase Blau 1980, p. 280 (suplemento a la p. 13).
} 
como Hayyūğ y fundador de esta escuela; Abū-l-Walīd Marwān Ibn Ğanāḥ (Córdoba c. 990 - Zaragoza d. 1040) el más famoso de los filólogos hebreos; y Samuel Ibn Nagrella ha-Nagid (Córdoba 993 - Granada 1056) que llegó a ser visir de la taifa de Granada y primer poeta hebreo del denominado siglo de oro. En este período destacan los «Libros de verbos hebreos» ${ }^{14}$ y los «grandes diccionarios» ${ }^{15}$. La lengua estudiada en estas obras es exclusivamente hebrea.

Tras la aparición de la obra de Hayyūğ , en algún momento de la segunda mitad del siglo $\mathrm{x}$, parece que se produjo un silencio académico, bien para la asimilación de conceptos, bien por la situación que provocó la interminable Gran Revuelta (al-fitna al-kubrà 1009-1031) que acabó con la soberanía omeya. Son décadas en las que los escritos de Hayyūğ se configuraron como una tradición (taqlīd) de indudable fidelidad ${ }^{16}$. Según lo que sabemos, Ibn Ğanāḥ, en plena juventud, fue el primero en romper este silencio académico y tras leerse la Biblia hebrea completa ocho veces, redactó alrededor del 1012 su Kitāb al-Mustalhaq 'Libro anexo'17, en el que, tras adoptar la estructura del Libro de Hayyūğ, revisaba y completaba la labor del más afamado maestro de la lengua hebrea $^{18}$. Ibn Ğanāḥ adoptó a pie juntillas la teoría de Hayyūğ, elaboró su

${ }^{14}$ Los Kutub al-af'äl 'Libros de verbos', en su origen islámico, se centraban solamente en las formas primera ( $f a^{\prime} a l a$ ) y cuarta ( $\left.a f^{\prime} a l a\right)$ del verbo trilítero árabe. Solían ir acompañados de un estudio sobre los esquemas morfológicos que resultaban de la derivación. Estas teorías quedaban recogidas en los prólogos, mientras que en los apéndices finales de cada capítulo se incluían reglas específicas, significados de las formas derivadas, tipos de mașdar, participios, nombres de lugar, etc. En definitiva, había una gran preocupación por la exacta vocalización de las palabras y una importante preeminencia de las estructuras sobre los significados. Algunos autores decidieron comenzar sus obras con un ensalzamiento de la lengua y una revisión de la labor lexicográfica de los gramáticos precedentes. Algunos diccionarios vocalizaban las entradas mientras que otros preferían indicar las vocales del individuo tratado mediante ejemplos o modelos. Los dos Kutub al-af'äl de Hayyūğ se inspiran en este género. A la forma primera (pa'al) y cuarta (hifil), añade la segunda (pi'el), mientras que el resto de las formas (nif'al, hitpa' el, huf'al y pu'al) son derivadas de las primeras. La forma primera ( $\left.p a^{\prime} a l\right)$ es considerada la ligera, desde un punto de vista fonético; la segunda (pi'el) y la cuarta (hif'il) son pesadas. Huf'al y pu'al son pasivas; nif'al parece ser tratado como una forma derivada de pa'al; por último, hitpa'el nunca recibe la denominación de pesada en estos dos trabajos, por lo que hay que entenderla como derivada. Estos tratados sobre verbos hebreos van precedidos de prólogos gramaticales en los que se explica la naturaleza de los diferentes géneros. Los casos siempre van acompañados de numerosos ejemplos extraídos de la Biblia que confirman el argumento, ya se trate de formas analógicas reconstruidas por el autor, ya para indicar la vocalización del caso en cuestión. A continuación se colocaban los diccionarios de verbos, uno para cada género, en los que las formas siguen un estricto orden morfológico. El Kitāb Hayyūğ 'Libro de Hayyūğ' está compuesto por el Kitāb al-'af'āl dawāt hurūf al-līn wa-l-madd 'Libro de verbos que tienen letras débiles y de alargamiento' y el Kîtāb al-'af'äl dawāt al-mitlayn 'Libro de verbos que tienen geminadas'. Ambos fueron editados por Jastrow 1897 y traducidos al castellano por Martínez Delgado 2004a.

${ }^{15}$ Estos diccionarios son dos: el Kitāab al-Istiğnă’ de Ibn Nagrella (Kokóvtsov 1916a) y el Kitāa al-Ușūl de Ibn Ğanāh (Neubauer 1875).

${ }^{16}$ En las fuentes se nos conservan apuntes y referencias sobre determinados filólogos como Yonah Ibn Ḥasday o Abū 'Amr Ibn Yaqwà entre otros, pero poco puede sacarse en claro, a lo más que tuvieron una intensa actividad docente entre finales del siglo x y comienzos del XI en Lucena y Córdoba.

${ }^{17}$ En este caso se entiende que la voz árabe al-Mustalhaq tiene el sentido de «anexo» al libro de Hayyūğ y no el de «anexión», véase Téné 2006, pp. XxxvII-XxxvIII.

${ }^{18}$ Aunque no pretendía ofender a nadie, esta obra, más o menos extensa, desencadenó una disputa filológica intensa entre Ibn Ğanāḥ e Ibn Nagrella (discípulo directo de Ḥayyūğ según la tradición) de la que sólo nos ha llegado la parte redactada por Ibn Ğanāḥ. 
discurso sobre sus conclusiones y las llevó a su máximo apogeo y difusión, construyendo su obra a partir de éstas. Los libros de verbos, por lo general, contienen análisis morfológicos y suelen dejar de lado la información referida al contenido de la voz analizada, que se da por sabida ${ }^{19}$.

Los «grandes diccionarios» son dos: el Kitāb al-ușūl 'Libro de raíces' de Ibn Ğanāh y el Kitāb al-Istignnă' 'Libro de la opulencia' de Ibn Nagrella. El contenido de los artículos del primero carece aparentemente de normalización, quizá por influencia de los léxicos árabes, de marcada naturaleza antológica y miscelánea. En sus análisis se da preferencia a la información morfológica de la voz y son varios centenares los artículos que carecen de definición. Aunque por lo general los límites entre exégesis, lexicografía y gramática no resultan claros en esta obra, lo cierto es que su planta se configuró como modelo para el resto de los diccionarios. Parece que su naturaleza antológica y su traducción hebrea, realizada por Yěhudah Ibn Tibbon (c. 1120 - c. 1190) ${ }^{20}$, fueron quizá los factores que más ayudaron a su tremenda difusión. El segundo gran diccionario, el Kitāb al-Istignn $\bar{a}$ ' 'Libro de la opulencia', ensaya un intento de normalización tripartita de los artículos: el primer enunciado o sección contenía la lista de todos los significados de la raíz según un orden sistemático; el segundo ofrecía testimonios de la literatura exegético-filológica hebrea antigua acerca de la interpretación de palabras derivadas de una misma raíz con muestras bíblicas; y el tercero mostraba a manera de inventario las formas gramaticales de dicha raíz registradas en la Biblia ${ }^{21}$.

\subsection{Período creativo (mediados del siglo XI - comienzos del siglo XII)}

Fijados los presupuestos básicos y las reglas generales en los libros de verbos del período anterior, comienzan a aparecer opúsculos monográficos con forma lexicográfica redactados en árabe y dedicados a facetas específicas de la lengua, como las partículas, las asonancias, el uso del género en la lengua hebrea, o la semitística comparada. Los autores que destacan durante este período son Mošeh ha-Kohen Ibn Chiqatella (siglo XI) ${ }^{22}$, Yěhudah Ibn Bil'am (siglo

\footnotetext{
${ }^{19}$ El título del desaparecido Kitāa al-tașārinf'Libro de las conjugaciones' de Ibn Yašuš (comienzos del siglo XI) parece referirse a otro libro de verbos.

${ }^{20}$ Bacher 1896.

${ }^{21}$ Sobre la labor lexicográfica de Ibn Nagrella véase Kokóvtsov 1916a, pp. 74-194. Existe una traducción castellana por Nikolaeva 2006.

${ }^{22}$ Los fragmentos del Kitāb al-tadkîr wa-l-ta'nit 'Libro del masculino y el femenino' de Mošeh Ibn Chiqatella fueron publicados por Allony 1949. Eldar 1998 dio a conocer un nuevo fragmento. Todos los materiales han sido recopilados en Martínez 2008a. El apellido Ibn Chiqatella está presente en todas las épocas o períodos de al-Andalus. Por asociación con chico no es difícil encontrar la versión castellanizada Ibn Chiquitilla. Sin embargo, la propia forma del nombre (גקטילה ğgtylh) y un pasaje hebreo de naturaleza irónica compuesto en Córdoba por Ibn Šešat en la segunda mitad del siglo x, parecen apuntar hacia al diminutivo de la voz romance chica, a partir del latín caecus, es decir, Chiqatella 'cieguecita' o 'cegatilla': הלא גדולכם בן ציקטלה / האור מאור שמש אפלה ¿No es vuestro sol Ibn Chiqatella? La luz del sol, un sol nublado» (Varela 1981, p. 13*). Aunque muchos consideran que el calificativo gadol
} 
XI) ${ }^{23}$ y Yiṣ̣haq Ibn Barūn (m. d. 1135) $)^{24}$. Estas obras resultaron muy prácticas y fueron de mucha utilidad para los poetas judíos que empleaban el hebreo en sus composiciones. Al final de este período, o quizá haya que encuadrarlo en otro específico, Ya‘ăqob ben El'azar (siglos XII-XIII) redactará en árabe una obra de capital importancia en la Toledo cristiana, el Kitāb al-Kāmil 'Libro completo', que pretenderá resumir y recopilar toda la producción andalusí25.

\subsection{Período de difusión (siglo XII)}

Invadida la Península Ibérica por las huestes norteafricanas, los judíos tendrán que emigrar a tierras cristianas. Durante este período los autores emplearán la lengua hebrea en sus redacciones para dar difusión a sus compendios lexicográficos. Así conseguirán llevar el legado andalusí hebreo fuera de la Península, enriqueciendo las bases lingüístico-culturales de la diáspora asentada en el norte de la costa mediterránea. Las obras que destacan en este período son el Mahberet he-'Aruk redactado alrededor de 1160 en Salerno (Italia) por Salomón ben Parhọon de Calatayud ${ }^{26}$ y el Sefer haŠrašim 'Libro de raíces' de David Qimḥ̄ (1160? - 1135?) en Provenza ${ }^{27}$. Por lo general, se inspiran en el Kïtāb al-usūul 'Libro de raíces' de Ibn Ğanāḥ y en

'mayor' se refiere a la edad, en esta ocasión Ibn Šešat podría estar jugando con Génesis 1,16: «E hizo Dios las dos grandes luminarias (ha-mě̀orot ha-gédolim), la luminaria mayor (ha-ma'or ha-gadol) para regir al día y la luminaria menor para regir la noche, y las estrellas». De ser así, Ibn Chiqatella no tendría que ser el mayor de los tres en edad sino en sapiencia, pues se le compara con el sol, algo así como «¿no es vuestro sol Ibn Chiqatella?». El significado de su apellido romance, «hijo de la cieguecita/cegatilla», haría el resto y habría que leer ha-'or ma'or šemeš 'afela. De hecho, Simonet 1888, p. 161, traduce chíca como 'neblina ó niebla' que es la traducción directa del término hebreo 'afela empleado por Ibn Šešat y alude, además a la etimología caecus fijada por Pedro de Alcalá. Para el contexto irónico del pasaje y otra lectura propuesta que consiste en leer ha-'or me-'or šemeš 'afela «que luce más que la luz del sol en la oscuridad», v. Sáenz Badillos - Targarona 1988, pp. 65-70.

${ }^{23}$ Los fragmentos del Kìtāb al-tağnīs 'Libro de las asonancias', Kitäb hurūf al-ma'anà 'Libro de las partículas' y del Kitāb al-af'äl al-muštaqqa min al-asmā' 'Libro de los deverbativos' de Yěhudah Ibn Bil'am fueron editados originalmente por Kokóvtsov 1916 y reeditados en Abramson 1975, junto con los fragmentos de sus traducciones hebreas.

${ }^{24}$ Existen dos ediciones completas del Kïtāb al-muwāzana bayn al-luğa al-'ibrāniyya wa-l-'arabiyya 'Libro de la equivalencia de la lengua hebrea y árabe'. Una en grafía hebrea en Kokóvtsov 1890; a la que añadió nuevos fragmentos en Kokóvtsov 1916b; y otra edición en grafía árabe por Hawaydī 1999. Junto a éstas, existe una versión inglesa, parafraseada, en Wechter 1964, que viene a difundir en inglés las conclusiones del orientalista ruso Kokóvtsov. Se ha anunciado una nueva edición en Becker 2005. Sobre este autor y su obra puede verse Martínez Delgado 2006.

${ }^{25}$ Únicamente conocemos un fragmento de la introducción publicado en Allony 1977. Creo haber identificado cinco nuevos fragmentos en el manuscrito II528 de la colección Firkovich y di a conocer mis primeros resultados en el congreso internacional La cultura judeo-árabe en al-Andalus celebrado en Córdoba durante los días 25-28 de junio de 2007. Junto con la introducción, N. Allony publicó unos fragmentos que consideró parte del Kïtāb al-Kâmil; la realidad es que el contenido y su disposición se parece más a un libro de verbos de finales del siglo x o comienzos del siglo xI que a lo que tuvo que ser una obra lexicográfica de los siglos XII-XIII.

${ }^{26}$ El Mahberet he-Aruk de Ibn Parhon se publicó en Stern 1884.

${ }^{27}$ El Sefer ha-Šrašm de David Qimhi fue publicado por Biesenthal y Lebrecht 1847. 
el Kitāb al-Kāmil de Ya'ăqob ben El'azar. A pesar de que ambas obras tienen una sección o volumen dedicado a la gramática, el análisis morfológico sigue contando con un lugar privilegiado en ambos léxicos, especialmente en el caso de David Qimhi, el más famoso de los dos. Lo interesante en este período son los móviles academicistas y la conciencia de que la lexicografía hebrea ya tenía su propia historia, tal y como muestra la introducción del Mahberet he-Aruk de Salomón ben Parhonon ${ }^{28}$ :

Cuando me percaté, soy Šĕlomoh ben Rabí Abraham, conocido como Ibn Parḥon de la ciudad de Qala'at <al-Yub> (Calatayud), de que el Mahberet de Mĕnahem ben Saruq, que en paz descanse, estaba en manos de la gente y de que era el preferido por ellos, comprendí que carecían de los otros comentarios elaborados por los últimos «príncipes de la Escritura» redactados en la lengua de Agar (árabe), como por ejemplo el Sefer Hayyǚ̆, q.e.p.d.,... A continuación apareció tras él Rabí Yonah, q.e.p.d., conocido como Ibn Ğanāḥ que siguió su método y aprendió de sus palabras, concluyendo que este libro no resultaba suficiente para la gente, poniendo de manifiesto sus olvidos y descuidos según la disposición del libro original y viéndose en la necesidad de redactar una obra a la que llamó Mustalhaq 'anexo'. En su época vivió un hombre muy importante entre los israelitas, nuestro rabí Šěmu'el ha-Nagīd (Ibn Nagrella), q.e.p.d., que se enfadó sobremanera por las observaciones a su maestro y por haber puesto de manifiesto sus olvidos y descuidos, así que se apresuró a replicar las opiniones del Rabí Yonah antes mencionado, viéndose en la necesidad de componer un tratado en el que exponer sus ideas, con razón hizo lo que hizo... En su época vivió Rabí Šělomoh (Ibn Gabirol) el Chico, q.e.p.d. el justo, que entendía las opiniones y discusiones de ambos sobre los asuntos de la Escritura. Consideró oportuno componer un Mahberet en el que explicó todas las letras del alefato, ayudándole su buena estrella, pues era un gran poeta ${ }^{29}$; aquellos pioneros sólo habían tratado las letras 'alef, he', waw y yod.

Además, Rabí Yonah, mencionado anteriormente, pensó que la Escritura necesitaba un 'aruk en el que convendría hablar de todo el alefato y lo compuso dejando de lado la disposición del < Sefer $>$ Hayy $\bar{u} \breve{g}$, la del Mustalhaq y la del Tašcerr, y redactó dos volúmenes. A la primera sección la denominó Sefer Luma 'Libro de los destellos' y a la segunda Libro de las raíces de las palabras. Cuando yo llegué a la ciudad de Salerno y vi que no tenían ninguno de estos comentarios, me propuse traducir todos estos libros mencionados a la lengua santa, pero no lo hice por separado como son en la lengua de Ismael, sino que preparé un 'Aruk 'Compendio'.

\subsection{Período de asimilación (siglos XIII-XIV)}

Durante este período aparecen por toda la cuenca mediterránea una serie de diccionarios redactados por autores que ya no son andalusíes pero que se inspiran en las obras producidas en la Península Ibérica. En la orilla norte

\footnotetext{
${ }^{28}$ Stern 1884, p. XII.

${ }^{29}$ Ibn Parhon se refiere al Anaq 'Collar', una gramática de hebreo bíblico redactada en verso por Ibn Gabirol (c. 1020 - c. 1057). La versión castellana de los fragmentos conservados puede encontrarse en Sáenz-Badillos 1980b.
} 
destaca el Diccionario anónimo de Provenza $a^{30}$, redactado en hebreo, y al sur el Kitāb al-Taysìr 'Libro de la facilidad', redactado en árabe en el Cairo antiguo ${ }^{31}$. En ambos se aprecian innovaciones en la técnica lexicográfica. El primero busca una normalización de sus artículos, diferenciando entre un primer enunciado, dedicado a las formas verbales o binyanim que las raíces emplean, y un segundo que recoge el significado de la raíz. Por otra parte, el Kitāb al-Taysīr 'Libro de la facilidad' es la primera obra lexicográfica, que tengamos constancia, en la que no se presta atención al análisis morfológico de las voces, sino que el interés repercute en los diferentes conceptos que puede llegar a expresar una misma raíz en diferentes contextos y circunstancias, asemejándose a lo que hoy se espera de un diccionario propiamente dicho.

\subsection{Período de decadencia (siglo XV)}

En la Granada nazarí, Sa ădyah Ibn Danān, el último autor judío de alAndalus, redactará el último léxico medieval andalusí, el Sefer ha-Šrašim 'Libro de raíces' en árabe ${ }^{32}$, segunda parte de una obra titulada al-Darūrì fì-l-luǵa al'ibrāniya 'Lo necesario acerca de la lengua hebrea' (1468). El Libro de las Raíces muestra una manera nueva de entender la lexicografía hebrea andalusí en la Península y ayuda a entender una secuencia evolutiva gravemente mutilada. Por primera vez desde la aparición de la obra de Hayyūğ, lo que importaba en realidad era el sentido básico de las palabras (haqiqua) y sus usos derivados (mutaqāriba), no su forma (tașñf), que se daba por sabida. Su aportación más personal consiste en aplicar un criterio maximalista a la hora de tratar las acepciones, si bien, en ocasiones llega a dividir lo que no es divisible y a catalogar hasta quince acepciones allí donde no hay más de tres. Su autor llega a prestar más atención a la traducción árabe de cada palabra que al clásico recurso de la evolución o uso metafórico del sentido de las raíces. Con todo, como colofón a la historia de estos cinco siglos, el diccionario es precioso y muy crítico con el pasado. Entre sus innovaciones destacan algunas ilustraciones del autor.

\section{LOS ORÍGENES DE LA LEXICOGRAFÍA HEBREA ANDALUSÍ}

Normalmente el origen de los léxicos está en recopilaciones rudimentarias y básicas, denominadas glosarios y entendidos aquí como catálogos breves de palabras definidas o comentadas pertenecientes a un corpus determinado, en este caso la Biblia. Estos compendios básicos se configuraban como materiales escolares específicos, mientras que los diccionarios, más complejos y ambicio-

\footnotetext{
${ }^{30}$ Sáenz-Badillos 1987.

${ }^{31} \mathrm{El}$ Kitāb al-Taysìr se conserva en numerosos manuscritos de la colección Firkovich. En la actualidad estoy ultimando su edición crítica que espero pronto vea la luz.

${ }^{32}$ Editado en Jiménez Sánchez 1996 y traducido al castellano íntegramente en Jiménez Sánchez 2004.
} 
sos, pretendían abarcar la totalidad del lenguaje. Esta producción «primitiva» no estaba aún bajo la poderosa influencia de la cultura árabe, sino que surgió a partir de la contemplación de las listas elaboradas por los masoretas y que, según parece, en ojos de los usuarios tomaron el papel de glosarios. Así se confirma a partir de importantes y antiguas obras como el Egron de Sa‘ădya ha$\mathrm{Ga}^{\prime}{ }^{33}$, en lo que toca a los orígenes de la lexicografía, o el Diqduqe ha-țě́amim de Aharon ben $\mathrm{Ašer}^{34}$, en lo que se refiere a los orígenes de la gramática.

\subsection{La Masora}

En sus orígenes, la técnica lexicográfica, tal y como la desarrollaron los judíos en la península Ibérica, empleó las listas elaboradas por los masoretas a manera de glosarios de los que extraer individuos analizables ${ }^{35}$. Por lo general, toda producción lexicográfica, sea de la lengua o cultura que sea, tiene su origen en glosarios. En el caso de los judíos, determinadas listas o colecciones masoréticas se configuraron como glosarios carentes de definición. La literatura masorética es muy antigua. Se encargaba de conservar y transmitir la integridad del texto bíblico en todos sus niveles, recopilando en forma de listas aquellas palabras que los escribas consideraban que los copistas debían memorizar y tener en cuenta para no errar en su labor de transmisión del texto bíblico. Con el tiempo fue evolucionando y configurándose como lo que se ha denominado Masora acumulativa. Aparecieron entonces listasglosarios más complejas que fomentaron el estudio de las relaciones creadas entre las palabras bíblicas, inaugurándose la lexicografía hebrea medieval. Estas listas fueron recopiladas en colecciones medievales muy tempranas,

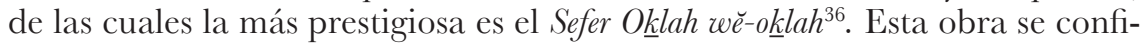
guró como uno de los manuales básicos de los filólogos hebreos medievales, pues en determinadas listas se concentran una serie de formas, o elementos a analizar, cuyas peculiaridades ayudaron en cierta manera a entender la naturaleza de la lengua hebrea bíblica ${ }^{37}$. De ahí que en los orígenes, la $M a^{-}$ sora pasase a ser la fuente secundaria principal del lexicógrafo hebreo. El análisis de cada una de las voces recogidas en estas listas-glosarios confirió al estudio de la lengua hebrea un carácter más lexicográfico que gramatical

\footnotetext{
${ }^{33}$ Allony 1969.

${ }^{34}$ Dotan 1967.

${ }^{35}$ Dotan 1990.

${ }^{36}$ Díaz Esteban 1975. Dotan 2005 p. 110 demuestra que este compendio fue conocido en la Edad Media como al-Masora al-Kabìra (La Gran Masora).

${ }^{37}$ Por ejemplo, la lista número 60 del Sefer Okla we-Okla: «Lista de palabras que aparecen dos veces <en la Biblia> con diferente significado» (Díaz Esteban 1975); y véase su estudio monográfico como glosario lexicográfico en Dotan 2005. De la misma manera, la lista 88 de la misma obra «doce palabras con 'alef final que no debe leerse» contiene muchos de los ejemplos empleados por Hayyūğ para desarrollar diferentes puntos de su teoría.
} 
desde sus orígenes ${ }^{38}$. De hecho, la gramática, tal y como la entendemos hoy, no aparece en al-Andalus hasta el siglo XI, cuando Ibn Ğanāh de Córdoba adaptó los criterios árabes para sistematizar la primera gramática completa de la lengua hebrea ${ }^{39}$, a la que además añade en un volumen independiente el primer léxico gramatical del hebreo bíblico de la historia, en un intento de diferenciar ambas disciplinas. En su introducción, Ibn Ğanāh explica la naturaleza de los contenidos de su diccionario y exige del lector que emplee la ley de la sinonimia allí donde sea necesario ${ }^{40}$ :

Dijo Abū-l-Walīd Marwān Ibn Ğanāḥ: Ya hemos presentado en la primera parte de este compendio, qué es el Kitāb al-Luma 'Libro de los destellos'"1, los capítulos de la disciplina: la sintaxis, los principios analógicos y los conceptos gramaticales obligatorios y necesarios para el interesado en la ciencia del lenguaje. En esta segunda parte, que hemos denominado Kitāb al-ușul 'Libro de raíces', recogeremos la mayoría de las raíces hebreas registradas de lo que conservamos en la Biblia. Presentaremos sus derivaciones y explicaremos todo lo que venga al caso hasta agotarlo dentro de nuestras posibilidades, tras insistir en ello y haber sido minuciosos, pues así ha de obrarse cuando se interpreta la palabra de Dios, fuerte y venerado. A Dios le ruego que me proteja del pecado (de equivocarme) y me dirija hacia la verdad por medio de su gracia. No puede exigirme nadie que presente todas las voces que hay bajo todas las acepciones, pues si así lo hiciese tendría que presentar toda la Escritura, sino que presentaré de cada acepción lo que yo considere suficiente. Cuando te aparezca una palabra con sentido polivalente y no encuentres su significado, deberás buscar la raíz a la que pertenece, si la encuentras bien y, si no, búscala en todas las acepciones que tenga dicha raíz y encájala donde mejor le convenga y se aproxime más.

\subsection{Los glosarios bíblicos bilingües}

Como puede intuirse, la diferencia entre lista masorética y diccionario es amplia y puede que insalvable. Por un lado, el masoreta pretende recoger y llamar la atención sobre una forma específica, si no extraña, al menos peculiar

\footnotetext{
${ }^{38}$ Esta naturaleza lexicográfica llega incluso a quedar fosilizada en la forma de los tratados exegéticos, que podríamos definir como comentario de nota a pie de página y en los que, en realidad, se discutía el sentido de determinadas palabras.

${ }^{39}$ Derenbourg 1886; Becker 1998. Puede verse, además, Sáenz-Badillos - Targarona 1988, pp. 109-147.

${ }^{40}$ Neubauer 1875, columna 1, 5-23.

${ }^{41}$ Aunque tradicionalmente se le conoce como Le Livre des Parterres Fleuris 'Libro de los arriates en flor', nombre que le dio Derenbourg al editarlo (1886), en este caso parece más apropiado respetar el original y leer 'Libro de los destellos'. Derenbourg basa su propuesta en un pasaje del propio Ibn Ganāh, que al final de la introducción afirma: «dada la diversidad de sus materias, he denominado a esta sección Kitāb al-luma', comparando sus capítulos con los destellos del suelo que se dan en los lugares en los que hay diferentes variedades de flores, tomándolo de los brillos de los vestidos con tonalidades diversas» (Blau 1980b, pp. 121-122). Entender el plural árabe luma como arriates exige una licencia que no avala diccionario alguno conocido. Por otra parte, la voz luma ${ }^{`}$ es muy frecuente en trabajos de lingüística árabe elaborados a lo largo del medievo, destacando el de Ibn Ğinn̄̄ (932-1002) entre otros. A esta posible similitud alude ya Becker 1998, p. 11, n. 30.
} 
(denominada en la literatura filológica árabe garīb) sin atender explícitamente a su significado, mientras que el autor de un diccionario está más preocupado por el contenido de un grupo de palabras afines y de las variaciones de sentido que puede provocar el contexto. Si, además, el diccionario es bilingüe, se intuye una preocupación o una búsqueda y actualización de los sentidos de las palabras por medio de la lengua empleada en la vida diaria.

Resulta evidente, por tanto, que entre lista masorética y diccionario debe existir un eslabón intermedio en el que se desarrollen estas técnicas que encontramos ya fosilizadas en los diccionarios. Todos los datos apuntan a los glosarios bíblicos bilingües. Estas redacciones se encuadran en el marco de las traducciones bíblicas al ser listas de voces pertenecientes al corpus de las Escrituras acompañadas de un equivalente árabe. El reciente descubrimiento de glosarios bíblicos en judeo-árabe en la Geniza de El Cairo ${ }^{42}$ ha puesto de manifiesto que estas redacciones parecen ser, además, el origen de las traducciones árabes de la Biblia ${ }^{43}$. Por lo tanto, el origen de estos glosarios debe datarse en la época de expansión de la lengua árabe (siglo Ix) y su función parece ser didáctica; se trata, en definitiva, de que el creyente entienda la Biblia en la lengua empleada en la vida diaria. Los glosarios conservados en la Geniza de El Cairo sobrepasan el medio centenar, unos son bíblicos, otros dedicados a la lengua de la Mišnah, el Talmud e incluso mixtos, es decir, dedicados a diferentes obras a la vez. Por lo general son denominados en árabe tafsìr al-alfäz o šarh al-alfāz entre otros nombres. En los bíblicos, por lo general, se recoge la palabra tal cual aparece en la Biblia, separada por un punto o guión del equivalente árabe ofrecido por el autor. La voz árabe pretende aclarar la voz hebrea recogida, ya sea su forma gramatical, ya sea su valor en el contexto. Estos equivalentes no son aun una definición tal y como se entiende en un diccionario. Los investigadores que han dedicado su tiempo a estos glosarios conservados en esta colección concluyen que pueden dividirse en cuatro grupos o tipos ${ }^{44}$ :

a. glosarios de palabras que se suceden según el orden que aparecen en la Biblia pero despojadas de partículas y componentes ajenos a la voz en cuestión.

b. glosarios de palabras de difícil interpretación que siguen el orden en el que aparecen en la Biblia y que se dividen en perícopas o libros bíblicos.

c. glosarios de palabras de difícil interpretación seleccionadas de manera aleatoria y sin criterio aparente, por lo que resulta sumamente complicado adscribirles una función específica fuera de la antológica.

d. glosarios temáticos dedicados a parcelas determinadas del lenguaje, tales como la geología, botánica, zoología, etc.

${ }^{42}$ Además de en la Geniza de El Cairo, también se conservan glosarios bíblicos bilingües en la colección Firkovich de San Petersburgo.

${ }^{43}$ De hecho, hasta la década de los ochenta del siglo xx se pensó que la traducción árabe de la Biblia realizada por Să'adyah Ga'on fue la que inauguró estas versiones árabes tan difundidas en la Edad Media, comenzando lo que se ha denominado el período clásico de la literatura judeo-árabe, véase Gallego 2006, pp. 29-31 y especialmente las pp. 42-43.

${ }^{44}$ Blau y Hopkins 2000, Polliack y Somekh 2000, Eldar 2001. 
Según los especialistas ${ }^{45}$, en estas redacciones está el germen de las traducciones árabes de la Biblia porque estos glosarios muestran que los autores aún no tienen o sienten la necesidad de traducir todo el versículo, sino que se detienen única y exclusivamente en las voces que consideran o bien de difícil interpretación o bien oportunas. Sea como fuera, estos glosarios son una pieza importante para conocer la historia del desarrollo de la técnica lexicográfica hebrea por un lado y la historia de la interpretación de la Biblia por otro.

Sus características básicas son muy importantes y parecen demostrar que se trata de un género bien definido en su contexto y con una función muy clara: leer la Biblia en hebreo. Si se intenta establecer un criterio basado en la tipología de estos glosarios, unos contienen la expresión más simple de lo que puede ser un glosario. Por simple se entiende que la fórmula empleada es la básica desde un punto de vista lexicográfico: voz glosada + equivalente árabe + caso hebreo paralelo ${ }^{46}$; otros mostrarán fórmulas más complejas, es decir, por glosario complejo entiendo que a la secuencia básica se añadirán otras informaciones complementarias que pueden ser de tipo gramatical o exegético: voz glosada + equivalente árabe + caso hebreo paralelo + información complementaria ${ }^{47}$.

\section{Características Generales de la lexicografía Hebrea ANDAlusí}

Los inicios del estudio de la lengua hebrea en la Península Ibérica ${ }^{48}$, y fuera de ella ${ }^{49}$, tienen, generalmente, forma lexicográfica y siempre destacaron por contar con importantes tanteos, muy limitados pero con aspectos muy positivos que sirvieron para configurar el carácter cultural del judaísmo andalusí. Superada la primera etapa de experimentación y hallada la clave que hacía de la morfología algo que se podía entender desde la norma general, tras aplicar las teorías desarrolladas por los gramáticos árabes, los esfuerzos lexicográficos se centraron en agrupar los diferentes sentidos de las voces bí-

\footnotetext{
${ }^{45}$ Blau y Hopkins 2000, pp. 13-14 y, recientemente, Blau y Hopkins 2007.

${ }^{46}$ Un ejemplo de este tipo básico puede encontrarse en Martínez Delgado 2007a; sirva de ejemplo el caso de Génesis 24, 66: wa-yěsaper 'y contó', según u-lĕma'an těsaper bĕ-'ozne (Ex 10, 2 'para que cuentes a los oídos de').

${ }^{47}$ En el manuscrito I2324 de la colección Firkovich se conserva un fragmento (8 folios) de un glosario judeo-árabe al Libro de Jueces que presenta estas fórmulas más complejas y evolucionadas. Espero poder publicarlo en breve. Sirva de ejemplo el caso de Jueces 14,5: Kĕfir 'arayot 'león de presa' según tirmoš kêfir we-tanin (Sal 91,13 'rondarás leoncillos y dragones'); este nombre se empleaba específicamente para los (leones) que eran crías.

${ }^{48}$ Sáenz-Badillos 1986.

${ }^{49}$ Sirvan de ejemplo importantes y clásicos testigos como Ha-'Egron, Kitāb ușūl al-š̌r r al-'ibrāni de Sě‘adyah Ga'on (Allony 1969); Kitāb al-sab 'in lafża de Sĕ'adyah Ga'on (Allony 1958); Al-Risāla de Yěhuda Ibn Qurayš (Becker 1984); o el importantísimo The Hebrew-Arabic Dictionary of the Bible Known as Kitāb Jāmi' al-Alfäz (Agron) of David ben Abraham al-Fasi (Skoss 1936). Por otro lado, resulta más difícil rastrear el impacto del trabajo gramatical Kutub al-Lugia 'Libros de Lengua' de Sě'adyah Ga'on (Dotan 1997) en autores posteriores.
} 
blicas con las leyes e instrumentos ideados por los musulmanes para interpretar el Corán. Ya en el siglo x, Hayyūğ fundó una nueva escuela en Córdoba que, con el criterio descriptivo y analógico importado de Bagdad, analizó la vetusta lengua hebrea siguiendo las tendencias en boga entre los intelectuales de la lengua soberana. Su obra, que describía el comportamiento que tenían en la Biblia las letras denominadas por los árabes «débiles y de alargamiento» (hurūf al-līn wa-l-madd), supuso un antes y un después en la historia de la lengua hebrea ${ }^{50}$.

Basándose en la descripción de hechos generales, esta escuela trató, desde sus orígenes, de explicar los hechos lingüísticos como resultado de un proceso evolutivo, tanto a nivel semántico como morfológico. Así encontramos que, en la esfera de la semántica, el primer autor andalusí, Měnahem ben Saruq, mantiene que «la raíz se puede ir estirando cada vez más hasta el punto de poder dividirse en una sola o hasta en quince acepciones» ${ }^{51}$. Su discípulo, Hayyūğ, en el plano morfológico o de identificación de la raíz lema, mantiene que:

Guando a los hebreos les resultaba difícil pronunciar un verbo cuya primera, segunda o tercera radical fuese 'alef, waw, yod o demás, al emplearlo, vieron que las (letras) débiles y las quiescentes les facilitaban la realización y la vocalización, por lo que debilitaron lo que se realizaba en su forma original y enmudecieron de la forma básica lo que estaba vocalizado ${ }^{52}$.

El interés de la escuela de la Córdoba califal por centrarse, única y exclusivamente, en el hebreo bíblico fue quizá el factor que más marcó el desarrollo de la cultura judeo-andalusí a un nivel lingüístico. El hecho de que los antiguos israelitas pasasen a ser los auténticos responsables de alterar, por motivos fonéticos y retóricos, determinadas formas parece indicar que, en la concepción de esta escuela, el hebreo bíblico es un medio de comunicación humana del que solo se conserva una parte, la que expresa la Palabra de Dios y así encontramos testimonios precoces, ya en el siglo $\mathrm{x}$, que ponen el énfasis en este punto ${ }^{53}$ :

Si no hubiésemos sido desterrados de nuestra tierra, dispondríamos de toda nuestra lengua, como antaño, cuando habitábamos seguros en parajes tranquilos. Sólo entonces conoceríamos todas las particularidades de nuestro idioma, todas sus acepciones, dominaríamos sus metros y fijaríamos sus fronteras. Pues la lengua de cada pueblo tiene su métrica y su gramática, sólo que la nuestra se ha perdido por la magnitud del pecado, se nos ha ocultado por la gran culpa desde el día que salimos en diáspora. Tras haber sido amplia, ha quedado mermada y escondida, vedada. Si no fuese porque Dios obró milagros, al contemplar la indigencia de su pueblo, se hubiese perdido y consumido incluso lo poco que queda.

Parece que, inspirados por Porfirio ${ }^{54}$, llegaron a la conclusión de que, gramaticalmente, bajo el aspecto de determinadas formas explícitas (šajṣ 'indivi-

\footnotetext{
${ }^{50}$ Martínez Delgado 2004a.

${ }^{51}$ Sáenz-Badillos 1986, p.1*.

${ }^{52}$ Jastrow 1897, p. 23. Traducción castellana de Martínez Delgado 2004a, p. 53.

${ }^{53}$ Benavente Robles 1986, p. 15*:15-22.

${ }^{54}$ Martínez Delgado 2004b.
} 
duo') subyacían las formas originales (aṣl) que hacían a todas las categorías (nu'a 'especies') idénticas según un mismo criterio $^{55}$, y solo había que retrotraerlas a su estado primitivo o esencia. Desde un punto de vista lexicográfico, primero se identificaba la raíz morfológica (așl 'género'), a la que inmediatamente se le adscribía una o varias acepciones (nu'a 'especie'). A continuación, se recopilaban todas las muestras necesarias para conocer los diferentes usos (šajṣ 'individuos') provocados por el contexto, que podían ser rectos (haqiqqa), metafóricos (isti'ấra), figurados (mağāz), implícitos (taqdīr) o, como añadirá Maimónides, alegóricos (tašbīh).

Marcada por una severa dependencia del așl 'raíz árabe', en el proceso evolutivo de la lexicografia hebrea de al-Andalus, fue necesario redactar una serie de diccionarios morfológicos, en los que se explicaban los verbos débiles y geminados y en los que las definiciones quedaban implícitas o dadas por sabidas. Estos tratados lexicográficos causaron un gran impacto al identificarse en ellos morfología con fiabilidad y vinieron a inaugurar la etapa más importante de la técnica lexicográfica hebrea medieval ${ }^{56}$. Es obvio que el lexicógrafo, en su labor, se preocupa por averiguar el significado de las palabras, pero puesto que éste le viene dado por su forma, el autor tiene que conocer y ofrecer otros datos no semánticos, tales como la categorización gramatical, los contextos en los que se emplea, los desarrollos históricos, las variantes fónicas, etimologías léxicas, etc. Este factor ha llevado a definir la figura de Hayyūğ como padre de la gramática hebrea, si bien, la realidad es que, a pesar de estar más que cualificado para ello, él nunca redactó una gramática sino cuatro diccionarios morfológicos con breves introducciones con reglas generales sobre morfología. El impacto de su teoría lexicográfica, basada en el análisis morfológico, fue tal que hay que esperar a los últimos siglos de producción para encontrar que los diccionarios van dejando de lado la morfología, o dándola por sabida, para centrarse en el significado básico y sus derivados, comenzando a asemejarse por fin a lo que actualmente se espera de un diccionario ${ }^{57}$.

Como puede apreciarse, los límites entre lexicografía y gramática nunca han estado del todo claros. La lexicografía, entendida aquí como la disciplina ocupada en todo lo concerniente a los diccionarios, recopila y estudia palabras como elementos que pertenecen a paradigmas léxicos, mientras que la gramática hebrea medieval se encarga de entender las funciones y comportamientos de esas mismas unidades léxicas dentro de la oración a través de sus variaciones flexionales. Además, esta gramática solamente va a ocuparse de

${ }^{55}$ Hayyū débil, los de segunda radical débil, los de tercera radical débil y los geminados. Por otro lado, los verbos de primera radical nun no son un género específico en la división de Hayyūğ, pues el fenómeno que los caracteriza también se da en todas los formas nif'al, es decir, es una característica de la consonante, no de los verbos y de ahí que no los incluya como un género en sus tratados.

${ }^{56}$ Así lo confirma el Kìtāb al-Mustalhaq de Ibn Ğanāḥ (Derenbourg 1880; la versión hebrea del siglo XII puede encontrarse en Téné 2006) y el Kitāb al-Istignāa’ de Ibn Nagrella (Kokóvtsov 1916a).

${ }^{57}$ Como en el caso del último diccionario hebreo redactado en al-Andalus, el Sefer ha-Šrašim de Sě‘adyah Ibn Danān de Granada (1468). Edición de Jiménez Sánchez 1996; Jiménez Sánchez 2004. 
categorías, reglas generales y paradigmas flexionales y nunca lo hace palabra por palabra, salvo en caso de las voces gramaticales, que en el caso de las lenguas semíticas son las partículas. En este punto, en el tratamiento que de las partículas hace Yěhudah Ibn Bil'am (siglo XI) en su Kitāb hurūf al-ma'anà 'Tratado sobre las partículas' ${ }^{58}$, es donde mejor puede apreciarse la simbiosis entre gramática y lexicografía. La distinción de las categorías de las palabras es otro buen ejemplo, así, el Tratado sobre el género masculino y femenino de la lengua $h_{e b r e a^{59}}$ redactado por Mošeh ha-Kohen Ibn Chiqatella (siglo XI) muestra, en forma de trabajo lexicográfico, que el género es algo léxico aunque siempre condiciona la concordancia que es algo puramente sintáctico. Con todo y a pesar de la rica producción, la excesiva información referida al signo nunca llegó a desaparecer, pues desde sus orígenes, en los escritos de Hayyūğg, esta escuela fijó sus metas lexicográficas en la correcta catalogación de los verbos débiles y geminados. Esta ambigüedad interdisciplinaria y el peso del vetusto concepto Ars Grammatica parecen ser los motivos que han llevado hoy en día a denominar «gramáticos» hebreos a autores cuyas obras tienen, por lo general, forma lexicográfica.

El vocabulario estudiado en estos léxicos, distribuido en raíces lema, suele o pretende referirse bien a la totalidad de la Biblia ${ }^{60}$, o bien a determinadas parcelas de la lengua ${ }^{61}$. El carácter y límites del léxico contenido en cada una de las obras, aunque eminentemente bíblico, vienen condicionados por el concepto de lengua de cada autor. Así, en el siglo x, Mĕnahem ben Saruq entenderá el hebreo y el arameo bíblicos como un discurso indivisible que forma parte de una misma unidad, las Escrituras, mientras que Hayyūğ se centrará, influenciado por el purismo del anterior y por un sentido lingüístico más definido, en explicar la morfología del hebreo bíblico per se. Ya en el siglo XI, el fuerte móvil academicista llevará al más importante de todos los lexicógrafos hebreos de al-Andalus, Ibn Ğanah, a incluir en la microestructura de su obra el hebreo rabínico ${ }^{62}$. Se-

\footnotetext{
${ }^{58}$ Abramson 1975, pp. 89-142.

${ }^{59}$ Martínez 2008a.

${ }^{60}$ Como por ejemplo el caso del Mahberet de Mĕnahem ben Saruq (Sáenz-Badillos 1986), el Kitāb al-Istiginā' de Ibn Nagrella (Kokóvtsov 1916a), el Kitāb al-Ușūl de Ibn Ibn Ğanāh (Neubauer 1875), el Mahberet he-Aruk de Ibn Parḥon (Stern 1884) o el Sefer ha-Šrorašm de David Qimhị (Biesenthal y Lebrecht 1847).

${ }^{61}$ Como el caso del Kitāb Hayyū̆g (Jastrow 1897, Martínez Delgado 2004a), el Kitāb al-tad de Mošeh Ibn Chiqatella (Martínez 2008a), el Kìtāb al-tağnīs, Kittāb hurūf al-ma'anà o el Kitāâ al-af‘āl almuštaqqa min al-asmā' de Yĕhudah Ibn Bil'am (Abramson 1975) o el importantísimo Kitāb al-muwāzana bayn al-luğa al-'ibraniyya wa-l-'arabiyya de Yiṣhaq Ibn Barūn (Hawaydī 1999).

${ }^{62}$ Por cuestiones metodológicas, la lengua hebrea puede dividirse en cuatro grandes grupos: a) hebreo bíblico (siglos X-II a.C.); b) hebreo rabínico (siglos II a.C.-VI d.C.); c) hebreo medieval (siglos VI-XVI/XIX); y d) hebreo moderno (siglo XIX-hasta el presente). Para esta división véase Sáenz-Badillos 1988. Ben Hayyim prefiere dividir la lengua desde otra perspectiva: a) hebreo bíblico y rabínico (siglos X a.C.- II d.G.: el hebreo es una lengua hablada y literaria); b) hebreo medieval (siglos II-X: el hebreo es una lengua literaria y los que la emplean hablan otra lengua semítica, como el arameo o el árabe); c) hebreo medieval (siglos XI-XVIII: el hebreo es una lengua literaria y los que la emplean hablan una lengua no semítica); d) hebreo moderno (siglo XIX-hasta hoy: el hebreo es de nuevo una lengua hablada y literaria). Para esta división véase Ben Hayyim 1992.
} 
gún lo que conocemos, es en el siglo Xv, en el último diccionario redactado en al-Andalus, el de Ibn Danān, cuando se incluyen en la macroestructura raíces rabínicas como lemas en el capítulo de la letra waw. Por lo general, el capítulo dedicado a la letra waw en un diccionario de hebreo bíblico sólo contiene dos lemas $(w-w$ y $w-h-b)$. En este caso, Ibn Danān se aparta de la tradición y afirma ${ }^{63}$ :

No encontramos en los veinticuatro libros santos (= Biblia hebrea) ninguna palabra cuya primera radical sea una waw salvo estas dos solamente. Pero encontramos en la Mišnah y en el resto de los comentarios de nuestros rabinos -bendita sea su memoria- otras palabras cuya primera radical es una waw, que son palabras hebreas puras, y señalamos aquí las que se nos han ocurrido.

Por lo general, en los artículos y entradas de estos léxicos se tiene muy en cuenta la evolución fonética y semántica de las voces así como la comparación con otras palabras de idéntico o contrario significado ${ }^{64}$. Los recursos y herramientas lexicográficos más empleados dependen del contexto y son, entre otros, la sinonimia, la antonimia, la permuta de consonantes, el paralelismo bíblico o la comparación con otras lenguas semíticas. El siguiente artículo lexicográfico ('alef-bet), tomado del Mahberet de Měnaḥem ben Saruq (primera obra lexicográfica propiamente dicha), aglutina lo que más tarde se entenderán como tres raíces diferentes ('alef-bet, 'alef-bet-he'y 'alef-waw-bet), pero muestra de manera pionera las líneas y técnicas que se desarrollarán durante los siguientes quinientos años:

'alef-bet: Se distribuye en seis categorías (panim):

La primera categoría (mar'eh) es:

Padre ('ab) y madre (Ezequiel 22,7);

Patrón ('ăbī) de todos los que tañen la cítara (Génesis 4,21);

Trigo temprano ('abib) tostado (Levítico 2,14).

A pesar de que comparten un mismo aspecto (gráfico='alef-bet) se interpretan de manera diferente, ahora bien, tienen un mismo fundamento (semántico). Padre ('ab) y madre (Ezequiel 22,7) es «el padre biológico». Patrón ('ăbī) de todos los que tañen la cítara (Génesis 4,21) es «el padre» (o patrón) de todos los que tañen la cítara. Mientras que trigo temprano ('abib) (Levítico 2,14) es «la primera» de todas las primicias de los frutos, comienzo de toda cosecha, de ahí que se le denomine 'abib. Puede que de aquí se derive los frutos ('ibe) del prado (Cantar 6,11), por su humedad, su frescura y porque se tuesta con fuego. Esto último es más apropiado que lo primero, pues se aproxima más a su significado.

La segunda categoría (mar'eh) es y no quiso ('abah) $\mathrm{YHWH}$ (Deuteronomio 23,6); y no quisisteis ('ăbitem) subir (Ibidem 1,26); quiero ('abi) que se pruebe a fob eternamente (Job 34,36); y se anula la voluntad (ha-’ăbyonah) (Eclesiastés 12,5). Todas se derivan del mismo (concepto). Todas expresan «voluntad». La interpretación de quiero ('abi) que se pruebe a fob eternamente (Job 34,26) es «mi deseo y anhelo es que Job sea puesto a prueba eternamente». La interpretación de y se anula la voluntad (ha-’ăbyonah) (Ecle-

\footnotetext{
${ }^{63}$ Traducción de Jiménez Sánchez 2004, p. 129.

${ }^{64}$ Uno de los más interesantes es el Mahberet de Mĕnahem ben Saruq, cuya lengua tiene una clara función metalingǘstica, por ser una obra pionera, monolingüe y seguir un criterio pregramatical. Sobre este uso de la lengua bíblica para redactar una obra lexicográfica véase Sáenz-Badillos 1975 y Elwolde 1995.
} 
siastés 12,5) es «rebrota la lujuria en el hombre cuando se ha agotado su vigor».

La tercera es los frutos ('ibe) del prado (Cantar 6,11); estando aún fresco (bě-'ibo) no se corta (Job 8,12). La voz se interpreta como «la frescura del fruto». Los que hablaban arameo escribieron, con esta voz, su ramaje era hermoso y su fruto (wĕ-'inbeh) abundante (Daniel 4,9). (La traducción aramea de) no da su fruto (piryo) (Le 26,20) es no da su fruto ('ibeh) (Targum Onqelos Le 26,20) ${ }^{65}$.

La cuarta es como odres (kě-'obot) nuevos (Job 32,19). Esta palabra carece de análogo en la Ley, sin embargo, el contexto la ilustra y medio versículo informa sobre la otra mitad, a pesar de que hubiese sido suficiente con medio (versículo), se vuelve a repetir el concepto por segunda vez, por lo que resulta que un mismo concepto, se expresa dos veces en un mismo versículo ${ }^{66}$. De éstos hay muchos ejemplos. Estos son algunos versículos cuya mitad informa sobre la otra: prestad oído y escuchad mi voz; atended y escuchad lo que digo (Isaías 28,23); gotee como la lluvia mi doctrina; destile como el rocío lo que digo (Deuteronomio 32,2); olvida que el pie puede aplastarlos y que la bestia del campo puede pisotearlos (Job 39,15); huerto cerrado, manantial cegado (Cantar 4,12); amparando y salvando, perdonando e indultando (Isaías 31,5); los pies del pobre, los pasos de los humildes (Isaías 26,6); los atrajo en su red y los reunió en su copo (Habacuc 1,15); no navega por él barco de remos ni lo cruza navío potente (Isaías 33,21); el que trazó en el mar un camino y en las bravas aguas un sendero (Isaías 43,16); Efraim vio su enfermedad y Judá su llaga (Oseas 5,13 ); presuroso saqueo, rápido botín (Isaías 8,3). Como estos hay muchos en los dichos proféticos y en su momento los recogeré en el lugar que les corresponde. Volvamos al significado de helo en mi vientre, como vino sin escape, como el de los odres (kě-'obot) nuevos revienta (Job 32,19). 'Obot se interpreta como «odres de vino» que revientan cuando están colmados e hinchados.

La quinta es nigromante ('ob) y adivino (2Crónicas 33,6); y como la de un espectro (kĕ'ob) de la tierra < saldrá> tu voz (Isaías 29,4); una mujer que practique la nigromancia ('ob) (1Samuel 28,7); consulte espectro ('ob) u oráculo (Deuteronomio 18,11); acudid a los aparecidos (ha-'obot) y a los adivinos (Isaías 8,19). Todas son «la realización de sonidos que emiten los espectros».

La sexta es para quién los jah!, para quién los ayes ('ăboy) (Proverbios 23,29). Significa «tristeza», «duelo», depende del contexto. Puede que de ésta se derive «pobre» ('ebyon).

En muchas ocasiones, quizá demasiadas, el factor genético, esto es, la comparación con el arameo, primero, y con el árabe después, va a contar con una

${ }^{65}$ En este léxico la comparación lingüística es una herramienta más cuyo uso viene provocado por motivos lexicográficos. Así, cuando compara el hebreo bíblico con el arameo bíblico siempre recoge entradas que comparten las mismas radicales y una misma realización fonética. Se hace, además, un uso muy consecuente del Targum arameo (traducción de la Biblia). El proceso es simple: se recoge la palabra hebrea en cuestión, se busca su traducción aramea y, una vez localizada la raíz aramea, se busca su afín hebrea. Por ejemplo, en Cantar de los Cantares $(2,9)$ aparece la voz ha-hărakim, de sentido desconocido, pero en el Targum de Génesis $(26,8)$ encontramos que la forma hărakāa' traduce a la hebrea ha-halon 'ventana', por lo tanto, gracias al arameo, puede establecerse que en hebreo ha-hărakim y hahalon son sinónimos. Lo mismo ocurre en este caso presentado por Mĕnaḥem ben Saruq, la voz hebrea pri se traduce en arameo como 'ibe, por lo tanto, en hebreo, pri e ’ibe son sinónimos.

${ }^{66}$ Esta es la definición más básica de un frecuente recurso literario bíblico conocido como «paralelismo». 
presencia muy activa ${ }^{67}$. Parece que el arameo bíblico se empleará para entender la morfología de la palabra y así poder catalogar la voz bajo su correcto lema, mientras que el arameo targúmico y el árabe se emplearán más para aclarar el sentido de la voz en cuestión. El siguiente ejemplo está tomado de la obra comparativa por excelencia, el Kitāb al-muwāzana bayn al-luġa al-'ibrāniya wa-l-'arabiya 'Libro de la equivalencia de la lengua hebrea y la árabe' de Yiṣ̣aq ben Barūn ${ }^{68}$ :

'alef-bet-het

'ibhat hareb (Ezequiel 21,20). Esta palabra carece de pareja en el Texto. El sabio Abū-l-Walīd (Ibn Ğanāḥ), Dios lo tenga en su gloria, la tradujo «el brillo (lama'ān), el resplandor (bariq $)$ de la espada» por contexto. Nuestro maestro, Yěhudah Ibn Bil'am, indicó que significaba «el terror (hawef) de la espada» sin aducir prueba alguna. A mi parecer es afín al árabe y se traduce (al árabe) «la aniquilación (IstiBā $H$ at) de la espada», donde istibāhat es «saqueo, exterminio». Dijo 'Antara ${ }^{69}$ : «Hasta que aniquilaron (astabāh $\bar{u}$ ) a la familia de 'Awf con fuerza, / con espada y lanza del Yemen». La aniquilación se atribuye a la espada y a la lanza, por lo que resulta lícito que la misma acción se atribuya a la espada y se diga «la aniquilación (istibāhat) de la espada», de la misma manera que se dice «la espada le golpeó» y «la lanza le atravesó». En nuestro caso (en la Biblia hebrea), aparece un ejemplo de esto: la espada devora y se sacia (Jeremías 46,10$)$ atribuyendo ambas acciones a la espada. Lo que ayuda y apoya esta traducción es que dice 'al kol ša ‘ăhrehem natatti 'ibhat hareb (Ezequiel 21,20), es decir, «he puesto en sus puertas una espada para que los aniquile y extermine». Aunque mencione a continuación el resplandor por medio de la voz baraq, pues tal es su sentido recto, luego, al final del versículo, aparece la voz țabah, que es la acción referida a la espada y que culmina con la aniquilación y exterminio que ellos se merecen. Carece de sentido, por tanto, «para que aparezca el brillo (lama'ān) de la espada en sus puertas», pues esto exigiría un para ellos o contra ellos. Sin embargo el Texto no acepta más que una de estas dos posibilidades. Puesto que no he encontrado la etimología de esta voz, le he adscrito esta afinidad <con el árabe> porque resulta muy apropiada por contexto, lícita en este caso y apenas ejerce violencia

\footnotetext{
${ }^{67}$ Maman 2004.

${ }^{68}$ Kokóvtsov 1890, pp. 26-27.

69 'Antara es un poeta preislámico. Ibn Barūn controlaba a la perfección todas las fuentes tradicionales de los musulmanes, además de las contemporáneas. De ahí que en sus comparaciones de hebreo y árabe emplease con total soltura el Corán, el Hadīt, la poesía preislámica y la islámica, proverbios árabes e incluso aluda a los dialectos de Alhị̆āa y Himyar para argumentar sus exposiciones. En el plano de la literatura lingüística árabe sigue y cita a obras tan representativas como el Kitäb al-'ayn de

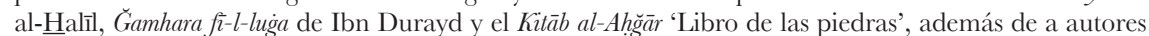
como al-Farrā' o Ibn Hanīfa. En cuanto a gramática, dominaba las dos supuestas escuelas, Kufa y Basora. Así encontramos dispersos por el Kitāb al-muwāzana bayn al-luġa al-'ibrāniyya wa-l-'arabiyya por un lado, a autores como al-Halīl, al-Mubarrad o al-Zağăğ̄i de Basora, y por otro, a al-Anbārī o a al-Farrā' de Kufa. Entre los andalusíes destaca al-Zubaydī. De hecho, Ibn Barūn llega a mezclar la terminología de ambas tendencias lingüísticas, y así encontramos que las letras serviles son denominadas hurūf aläliyya 'letras instrumentales' y que el genitivo se expresa por medio de la voz $\underline{h} a f s$, , esto es, nomenclatura cúfica. Su manejo del árabe y su literatura lingüística es magistral. En los fragmentos que conocemos llega a citar a diferentes sabios musulmanes en veinticuatro ocasiones, tres en la sección gramatical y veintiuna en la lexicográfica, e incluso se permite la licencia de corregir a al-Zubaydī en la forma árabe intabaha. Según el gramático musulmán es una forma infa'ala, sin embargo, para Ibn Barūn se trata de una forma ifta'ala, donde nun es la primera radical y no $t \bar{a}$ ' como pensaba al-Zubaydī en su al-kitāb alwä dị ‘El libro claro' (Martínez 2006).
} 
en la traducción, por eso las he relacionado. Algo similar le ocurrió al traductor (arameo) cuando dijo qatole harbă' "asesinados por la espada». Por su lado, rabí Hāy, Dios lo tenga en su gloria, la entendió como idéntica a 'ib'at 'terror', sustituyendo ayn (por hett) ${ }^{70}$.

En lo que toca a la macroestructura, cada una de las radicales iniciales de las voces cuenta con un capítulo exclusivo, resultando veintidós capítulos, uno por cada consonante del alefato. Con el paso del tiempo, en la época de difusión, David Qimhīe ya en Provenza, añadirá como colofón un apéndice de arameo bíblico ${ }^{71}$. Las raíces lema aparecen dispuestas siguiendo el orden alfabético-numérico tradicional ${ }^{72}$, a diferencia de la lexicografía árabe, que esta época tendía a la ordenación por rima ${ }^{73}$. Más del noventa y cinco por ciento de los lemas son trilíteros y siempre aparecen como lexías simples ${ }^{74}$.

En lo que se refiere a la microestructura los enunciados, o artículos, ofrecen dos niveles metalingüísticos. Por un lado el nivel que se refiere al signo, representado por indicaciones gramaticales variadas y que resulta el más desarrollado, puesto que a partir del siglo x morfología pasó a ser sinónimo de fiabilidad. Por otro lado, estos artículos suelen indicar el nivel que se refiere al contenido, es decir, la definición o equivalente árabe en caso de que sean diccionarios bilingües. Estas definiciones surgen tras aplicar la ley de la sustitución o sinonimia, siendo por lo general el equivalente un nombre. Con todo, hay que insistir en que la información referida al signo es la más desarrollada en general, a diferencia de lo que ocurre en la actualidad. En algunos casos, quizá demasiados, el autor se centra, o incluso obsesiona, únicamente con este nivel, llegando a no ofrecer una definición del término en cuestión. Es precisamente en la obra exegética por excelencia de Maimónides (1138-1204), Guía de perplejos $^{75}$, donde por primera vez encontramos un análisis lexicográfico dedicado exclusivamente al sentido y en el que no se habla de la información referida al signo, que se da por sabida.

Es en la obra filosófica de este importante pensador judío donde mejor se aprecia el impacto y autoridad de la lexicografía hebrea medieval en todas las disciplinas teológicas. Maimónides supone un antes y un después en la

\footnotetext{
${ }^{70} \mathrm{He}$ aquí un claro uso de permuta consonántica, muy extendido entre los filólogos medievales gracias al impulso que le dio Ibn Ğanāh como recurso exegético. Su origen puede rastrearse en la propia Masora acumulativa, que ya la empleaba para crear sinonimia entre palabras de realización similar. Sin embargo, no todos los autores van a ver este recurso con buenos ojos.

${ }^{71}$ Véase su Sefer ha-Š́orašim 'Libro de raíces' (Biesenthal y Lebrecht 1847).

${ }^{72}$ En ocasiones, en el caso de los verbos cóncavos la segunda radical no interfiere en el orden de las raíces, y en los diccionarios bilingües samek y sin se alternan entre sí al poseer una misma realización en judeoárabe.

${ }^{73}$ Sobre este punto y otros particulares puede verse Arias 1996.

${ }^{74}$ Las lenguas semíticas se caracterizan, morfológicamente, por la existencia de un morfema radical o raíz, generalmente de tres radicales, y de un morfema funcional o forma, esto es, la raíz con suplementos vocálicos y consonánticos que expresan los diferentes accidentes. Esto es lo que ocurre con la raíz s-l-m (estar sano y salvo), de la que se derivan los saludos, en árabe y hebreo, SaLāM-ŠLoM, o conceptos tipo iSLaM y muSuLMán. En lexicografia se empleará la raíz de tres radicales como lema.

${ }^{75}$ Munk 1930; Gonzalo Maeso 1984.
} 
historia de la lexicografía hebrea andalusí a pesar de que nunca redactase un diccionario. En la introducción a su Guía de perplejos elabora un curioso examen lexicográfico sin precedentes entre sus colegas. Si cada uno de los comentarios a nombres y verbos de esta introducción se entiende como un artículo lexicográfico, puede apreciarse su influencia en diccionarios redactados en alAndalus posteriormente como el Sefer ha-Šrašim 'Libro de raíces' de Sĕ'adyah Ibn Danān (siglo Xv), donde por primera y última vez desde la aparición de la obra de Hayyūğ (siglo x), lo que importaba realmente era el sentido básico de las palabras y sus usos derivados, no su forma, que se daba por sabida ${ }^{76}$.

Estos diccionarios pueden entenderse como claramente lingüísticos, pues su preocupación son los signos, nunca las cosas, de hecho no se estudian los nombres propios ni sus posibles etimologías. El corpus de la descripción lingüística suele ser exclusivamente bíblico y su concepción es sincrónica. Estos diccionarios de lengua hebrea clásica redactados en al-Andalus tratan de explicar, en teoría, los contenidos, o al menos ofrecer una pista que ayude a interpretar determinada voz o forma. Desde sus orígenes, los artículos presentan en sucesión estricta y premeditada la evolución semántico-morfológica de la raíz lema en cuestión mediante textos autorizados o šawāhid, es decir, pasajes bíblicos. La ordenación de acepciones suele ser lógica.

Las fuentes de las que se nutren estos diccionarios son, básicamente, de dos tipos. Por un lado lingüísticas, o primarias, es decir, el texto bíblico recibido y puntuado por los masoretas. Por otro lado, los autores cuentan siempre con fuentes metalingüísticas o secundarias, es decir, otras lenguas semíticas y otras obras lexicográficas propias o de otros autores. Este tipo es más libre y amplio que el anterior, pues todo lo que el autor considere aceptable será válido. Las lenguas empleadas en las comparaciones con mayor frecuencia son el arameo y el árabe. Por lo general, las otras obras no se citan si se va a extraer material de ellas; por el contrario, suelen aparecer correctamente citadas si se trata de criticarlas. Las fuentes escritas metalingüísticas o secundarias pueden dividirse en lexicográficas, es decir, otros diccionarios, y en no lexicográficas, que son, generalmente, comentarios exegéticos. Así, al menos, lo plantea Ibn Ğanāḥ en el primer diccionario de raíces de la historia, que por lo general, da por sabidas sus fuentes:

El que use este segundo volumen, me refiero al Kïtāb al-ușül 'Libro de raíces', necesitará saber todo lo que contiene el primero (dedicado a la gramática), es decir el Kitāb al-Luma ' 'Libro de los destellos', detenerse en ello, siguiendo nuestras indicaciones y nuestras incitaciones allí a retomar los libros de Abū Zakariya' (Hayyūğ)... y, además, a nuestros tratados Kïtāb al-Mustalhaq 'Libro anexo', Risāla al-tanbīh 'Epístola de admonición', Kitāb al-taqrīb wa-l-tashīl 'Libro de la aproximación y la facilitación', Kitāb al-tasw $\vec{\imath} a$ 'Libro de la reprobación' y Kitāb al-tašrwīr 'Libro del desenmasca-

\footnotetext{
${ }^{76}$ Lo cierto es que cada uno de los comentarios del análisis exegético de Maimónides en Guía de perplejos es similar a un artículo lexicográfico perfecto, pues pretende, ante todo, ofrecer una serie de informaciones en la que se da prioridad a la de tipo semántico. En este punto radica la gran aportación de Maimónides a esta técnica, enriqueciendo y actualizando el arte de componer diccionarios de hebreo bíblico. Sobre esta perspectiva véase Martínez Delgado 2008b.
} 
ramiento ${ }^{97}$. Todo esto le completará el conocimiento y le colmará el interés, pues todas estas obras son interesantes para el que emplee este volumen. Resulta, por tanto, imprescindible para el usuario detenerse en todo lo que hemos recopilado en el primer volumen, me refiero al Kitäb al-Luma 'Libro de los destellos', y concederle toda la importancia, pues lo hemos colmado de formas al recoger las relaciones de estructuras, voces raras y muchas y variadas acepciones que nos proporcionan un gran provecho para (entender) el funcionamiento de la lengua, sus realizaciones, sus usos y sus permutas. No hemos considerado necesario repetirlo todo en este volumen porque buscamos la facilidad y la brevedad. Quizá el usuario busque una de las raíces para saber qué se ha dicho sobre tal voz que está bajo determinada raíz y no la encuentre. Pensará que no hemos cumplido, sin embargo ya la hemos recogido en el primer volumen en alguno de sus capítulos.

Se trata, en definitiva, como puede apreciarse, de una disciplina claramente definida, una más de las que componen las ciencias del lenguaje (diqduq ha-lašon) de los judíos andalusíes. Todas estas disciplinas se unían en al-Andalus para elaborar una exégesis de carácter filológico y racional que trataba de evitar la perplejidad de los lectores de la Biblia. Así son a mi parecer, a grandes rasgos y generalizando, los períodos, autores y características principales de estos diccionarios.

\section{REFERENCIAS BIBLIOGRÁFICAS}

Abramson, S. (1975): Šĕloša sĕfarim šel R. Yěhuda ben Bil'am, Jerusalén.

Allony, N. (1949): «Š́reidey sefer 'al lašon zeker wě-lašon něqebah. Kitāb al-tad̄kīr wa-l-ta'nit lě Rabī Mošeh ha-Kohen Ibn Chiquitilla» Sinai 24, pp. 34-67 y 138147.

- (1958): Kitāb al-sab'in lafża, Sefer Zikaron li-kbod Y. Goldziher, vol. II, pp. 1-48.

- (1969): Ha-'Egron, Kitāb ușül al-šìr al-'ibrāni, Critical edition with introduction and commentary, Jerusalén.

- (1977): Ya ăqob ben El'azar Kitāb al-Kāmil, Jerusalén.

ARIAS, J. P. (1996): Un poco de lexicografia árabe, Málaga.

BACHER, W. (1896): Sepher haschoraschim, Wurzelwörterbuch der hebräischen Sprache von Abulwalìd Merwân Ibn Ğanâh (R. Jona) Aus dem Arabischen in's Hebräische übersetzt von Fehuda Ibn Tibbon, Berlín.

Becker, D. (1984): Al-Risāla šel Yěhuda Ibn Qurayš, Critical Edition, Tel Aviv.

- (1998): Mĕqorot 'araviyim lěediqduqo šel R. Yonah Ibn Ğanāh, Tel-Aviv.

- (2005): Mĕqorot 'ariviyim le-Yișhaq ben Barūn, Tel-Aviv.

Ben Hayyim, Z. (1992): Bë-milhamatah šel lašon, Jerusalén.

Benavente Robles, S. (1986): Těsubot de los Discípulos de Mĕnahem ben Saruq, Edición del texto y traducción castellana, revisada y completada por Á. Sáenz-Badillos, Granada.

Biesenthal, H. R. y Lebrecht, F. (1847): Rabbi Davidis Kimchi radiculum liber sive hebraeum bibliorum lexicon cum animadversionibus Eliae Levitae, Berlín.

BLACHÈre, R. (1973): «Refléxions sur le dévelopment de la lexicographie arabe». Revue de l'Occident Musulman et la Mediterranée 13-14, pp. 125-129.

\footnotetext{
${ }^{77}$ Todos ellos, a excepción del último que no se conserva, fueron editados y traducidos al francés en Derenbourg 1880. La versión hebrea del Kitāb al-Mustalhaq (siglo XII) puede encontrarse en Téné 2006. Recientemente se ha reeditado y traducido al castellano el Kitāb al-taswi'a en Gallego 2006.
} 
BLAU, J. (1980): Diqduq ha-'aravit ha-yehudit šel yime ha-benayim, $2^{\mathrm{a}}$ ed., Jerusalén.

- (1980b): Ha-sifrut ha-'aravit ha-yĕhudit, pĕraqim nibharim, Jerusalén.

- y Hopkins, S. (2000): «Tirgume Miqra' qĕdumin lě-'aravit-ha-yĕhudit», Pě́amim 83, pp. 4-14.

- (2007): «Nișane paršanut ha-Miqra' bě-'aravit ha-yěhudit 'al semek glosar qadum lě-Sefer Těhillim», A Word Fitly Spoken, Studies in Mediaeval Exegesis of the Hebrew Bible and the Qur'ān, Jerusalén, pp. 235-284.

Derenbourg, J. (1886): Le livre des parterres fleuris, Grammaire Hébrä̈que en Arabe d'Abou'l-Walid Merwan Ibn Djanah de Cordoue, París.

- y Derenbourg, H. (1880): Opuscules et traites d'Abou 'l-Walid Merwan Ibn Djanah de Cordóba, París.

Díaz Esteban, F. (1975): Sefer 'Oklah wĕ-'oklah, Madrid.

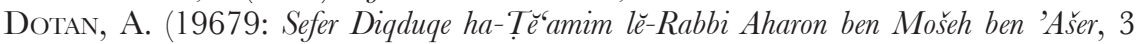
vols., Jerusalén.

- (1971): «Masora», Encyclopaedia fudaica, vol. 16, columnas 1401-1482, Jerusalén.

- (1990): «De la massora à la grammarie. Les débuts de la pensée grammaticale dans l'hebreu», Fournal Asiatique 278, pp. 13-30.

- (1997): The dawn of Hebrew linguistics, The book of elegance of the language of the Hebrews by Saadia Gaon, 2 vols., Jerusalén.

- (2005): Nișanim ri'sonim bĕ-hokmat ha-milim (The awakening of word lore, from the Masora to the beginnings of Hebrew lexicography), Jerusalén.

Eldar, I. (1998): "Qěța' nosaf min Kitäb al-tadkīr wa-l-ta’nit lĕ Rabī Mošeh ha-Kohen Ibn Chiquitilla», Ben ěver lé-'arav, Tel-Aviv, pp. 95-111.

- (2001): «Ha-glosografiah ha-miqra'it bĕ-'ezor ha-dibur ha-'aravi bĕ-mizraḥ», Ha-'Ivrit wë-'Ahyoteha 1, pp. 23-37.

Elwolde, J. F. (1995): «The Mahberet of Menahem - Proposals for a lexicographic theory, with sample translation and notes» en Davies, J., Harvey, G. y Watson, G. E. W. (eds.), Words remembered, texts Renewed. Essays in Honour of Fohn F.A. Saweyer, Sheffield, pp. 462-479.

Gallego, $\mathrm{M}^{\mathrm{a}}$ A. (2006): El judeo-árabe medieval; Edición, traducción y estudio lingüístico del Kitāb al-taswi'a de Yonah ibn Ğanāh, Berna.

Gonzalo Maeso, D. (1984): Maimónides, Guía de perplejos, Madrid.

Haywood, J. (1965): Arabic lexicography: Its history and its place in the general history of Lexicography, $2^{\text {a }}$ ed., Leiden.

HAwAYDī, A. M. (1999): Kitāb al-muwāzana bayn al-lugia al-'ibrāniyya wa-l-'arabiyya, Abū Ibrahìm Yishaq ben Barūn, El Cairo.

Jastrow, M. (1897): The weak and the geminative verbs in Hebrew by Abu Zakariyyâ Yahyâ ibn Dâwd of Fez, known as Hayyūğ, Leiden.

JimÉnez SÁnchez, M. (1996): Sefer ha-šorašim, Granada.

- (2004): Së‘adyah Ibn Danān: Libro de raices, Diccionario de hebreo bíblico, Granada.

KoKóvtsov, P. K. (1890): Yeter ha-pĕlitah min Kitāb al-muwāzana bayn al-luġa al-'́ibrāniyya wa-l-'arabiyya ašer hibro Abū Ibrahīm Tișhaq ben Barün ha-sefardī, San Petersburgo.

- (1916a): Novie Materiali dlya jarakteristiki Jehudi Jayudzam Samuila Naguida i nekotorï druguij predstaviteley yeureiskoy filologicheskoy nauki v X, XI $i$ XII veke, S. Petersburgo. (Los textos publicados en este volumen fueron reeditados por Allony como Me-Sifre ha-balšanut ha-'iorit byme ha-benayim Jerusalén 1970). 
- (1916b): Eyzeh liquțim ḥadašim min Kitāb al-muwāzana bayn al-luġa al-'ibrāniyya wal-'arabiyya lé-Abū Ibrahìm Yișhaq ben Barūn, San Petersburgo. (Los textos publicados en este volumen fueron reeditados por Allony como Me-Sifre ha-balšanut ha-'ivrit byme ha-benayim Jerusalén 1970).

Maman, A. (2004): Comparative Semitic philology in the Middle Ages: from Sa'adiah Gaon to Ibn Barūn $\left(10^{\text {th }}-12^{\text {th }}\right)$, trad., Lyons, D., Leiden-Boston.

Martínez Delgado, J. (2004a): Yahyà Ibn Dāwūd: El Libro de Hayyūğg (Versión original árabe siglo X). Introducción y Traducción, Granada.

- (2004b)): «The philosophical background of the Andalusian Hebrew Grammar $\left(10^{\text {th }}\right.$ Century)», Zutot 2003, pp. 42-48.

- (2006): La semitística comparada en Alandalús, de los orígenes a Ibn Barūn, Zaragoza.

- (2007a): «Fragmento de un glosario judeo-árabe del Libro de Génesis», Collectanea Christiana Orientalia 4, pp. 55-71.

— (2008a): «El Kitāb al-taḍkīr wa-l-ta'nīt de Mošeh Ibn Ğiqațela (S. XI)», Miscelánea de Estudios Árabes y Hebraicos (Sección de Árabe-Islam) 57, pp. 207-238.

- (2008b): "Maimonides in the context of Andalusian Hebrew lexicography», Alef: Historical Studies in Science and Fudaism 8, pp. 15-40.

Morag, S. (1985): «Reš’it ha-milona'ut ha-'ivrit wě-ha-'aravit». en Morag, S. y Eldar, I. (eds.), Studies on Medieval Hebrew linguistic thought. A Reader, Jerusalén, pp. 61-68.

Munk, S. (1930): Dalālat al-Hā̄ìñn, Jerusalén.

Neubauer, A. (1875): The Book of Hebrew Roots by Abu '-Watìd Marwān Ibn Fanāh, Oxford.

Nikolaeva, O. (2006): Samuel ha-Nagid como gramático y exegeta, volumen xi de Carlos del Valle, Historia de la gramática hebrea en España, Madrid.

Polliack, M. y Somekh, S. (2000): «Šěne glosarim miqra'yim 'ivrayim-'araviyim me-gěnizat Qahir», Pé'amim 83, pp. 15-47.

SÁEnz-Badillos (1975): Ángel Sáenz-Badillos, «En torno al Mahberet», Miscelánea de Estudios Árabes y Hebraicos 25, 2 (1975), pp. 11-50.

- (1980a): Těsubot de Dunaš ben Labtrat, Edición crítica y traducción, Granada.

- (1980b): «El 'Anaq, poema lingüístico de Šělomoh Ibn Gabirol» (ed. crítica y traducción castellana), Miscelánea de Estudios Árabes y Hebraicos 29, 2, pp. 5-29.

- (1986): Mahberet Mĕnahem. Edición crítica, introducción y notas, Granada.

- (1987): Un diccionario anónimo de Provenza (siglo XIII), Granada.

- (1988): Historia de la lengua hebrea, Sabadell.

— (2000): «Panorámica de la filología hebra en al-Andalus en la segunda mitad del s. XX», Miscelánea de Estudios Árabes y Hebraicos 49, pp. 105-146.

- y Targarona, J. (1988): Gramáticos hebreos de al-Andalus, Córdoba, pp. 23-89, reeditado como La escuela rabinica de Córdoba, Córdoba.

Schröter, R. (1866): Sefer Těšubot Dunaš ha-Levi ben Labrat 'al Rabī Sa'adyah Gaon, Breslavia.

Skoss, S. L. (1936): The Hebrew-Arabic Dictionary of the Bible known as Kitāb Fāmi' alAlfäz (Agron) of David ben Abraham al-Fasi, 2 vols., New Haven.

Stern, S. G. (1884): Mahberet he-'Aruk, Presburgo.

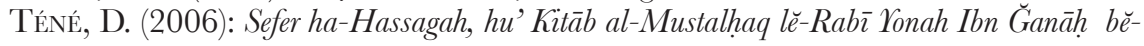
tirgumo ha-ibri šel 'Obadyah ha-Sefardī, Jerusalén. 
'Umar, A. (1982): Al-bahț al-lugaw̄̄ 'inda al-'arab ma'a dirāsa li-qadīyat al-ta'țīr wa-lta'attur, $4^{\mathrm{a}}$ ed., El Cairo.

Varela, E. (1981): Těšubot de Yěhudah Ibn Šešet, Edición, traducción y comentario, Granada.

Wechter, P. (1964): Ibn Barūn's Arabic Works on Hebrew Grammar and lexicography, Filadelfia.

Zubiri, X. (1994): Naturaleza, Historia, Dios, Madrid. 